\title{
Paskibraka Member Selection Using A Combination Of AHP and TOPSIS Methods On The Office Of Youth And Sports Of Kutai Kartanegara Regency
}

\author{
Septya Maharani ${ }^{1, *}$, Heliza Rahmania Hatta ${ }^{1}$, Afif Nur Anzhari $^{1}$, Dyna Marisa Khairina ${ }^{1}$ \\ ${ }^{1}$ Departemen of Computer Science. Faculty of Computer Science and Information Technology, Mulawarman Unversity, Samarinda- \\ Indonesia
}

\begin{abstract}
Paskibraka as troops whose job is to flap the heritage duplicates flag. To become a Paskibraka a selection that participants are high school students are made. Because the number of participants of the selection of many support systems to facilitate the assessment process is made. This system uses Analytical Hierarchy Process (AHP) to determine the weight value criteria that comprise the value of the interview, health, physical, .height and value rules for marching as well as using Technique For Others Preference by Similarity to Ideal Solution (TOPSIS) methods to seek best alternative participants. The calculation results of 21 alternative names best male and female of the participants and their school origin. The system has also been tested by performing the calculations manually using Microsoft Excel (Ms.Excel) to calculate the calculation of the system using AHP and TOPSIS.
\end{abstract}

\section{Introduction}

In Paskibraka elections a several main criteria on which to base an assessment is conducted. The assessment is then processed manually in order to get some of the names of the members elected Paskibraka. With so many alternative candidate members, it will take a long time in the selection process. To find the optimal alternative of a number of alternatives and certain criteria can use a decision support system with several methods namely Analytical Hierarchy Process (AHP) and Technique For Order Preference By Similarity To Ideal Solution (TOPSIS).

AHP is a method that uses human perception as the primary input for use as a base to look for eigenvalues, then determine Consistency Ratio. TOPSIS method to determine the best alternative solution [1].

Based on the description that has been presented, then built a system to help determine the election decision Paskibraka in Kutai Kartanegara regency using a combination of AHP and TOPSIS to find the best alternative solution.

\section{Literature review}

\subsection{Decision Support System}

Decision support system is a computer-assisted interactive system that supports the user in the ease of access to data and decision models in an effort to help the decision-making process effective in solving problems that are semi-structured and unstructured [2].

Decision support system (DSS) is an interactive information system that provides information, modeling, and data manipulation. This system is used to assist decision making in semi-structured and unstructured situations [3].

From the above understanding, it can be concluded that Decision Support System (DSS) is a computer-based information system that approaches to generate various alternative decisions to assist certain parties in dealing with problems using data and models. A DSS only provides an alternative decision and then submitted to the user to make a decision.

Decision-making is the result of a selection process from a variety of alternative actions that may be chosen by a particular mechanism, with the aim of producing the best decision. Where the decision process is gradual, systematic, consistent and in every step from the beginning has included all parties, will give good results.

\subsection{Paskibraka}

Pasukan Pengibar Bendera Pusaka, or more commonly known as PASKIBRAKA, is an army in charge of raising the duplicate of the heirloom flag in the commemoration ceremony of the proclamation of Indonesian independence on 17 August held in three places, namely the Regency / Municipal level (Office of the Regent / Mayor) Provincial (Governor's Office), and National (State Palace) [4]. 


\subsection{Analytical Hierarchy Process (AHP)}

Analytical Hierarchy Process (AHP) is one form of decision-making methods that use a functional hierarchy with the primary input is human perception. With hierarchy, something that is complex and unstructured broken into groups and then the group is set to be a form of hierarchy [5].

\subsection{Technique for order preference by similarity to ideal solution (TOPSIS)}

TOPSIS based on the concept that the best alternative was selected not only has the value of the shortest distance from the positive ideal solution, but it also has the longest distance value from the negative ideal solution. This concept is widely used in several models of Multi-Attribute Decision Making (MADM) to solve problems in a practical decision. This is due to the concept is simple and easy to understand, efficient computation, and has the ability to measure the relative performance of the alternatives in the form of a simple mathematical decision [6].

\section{Research methodologies}

\subsection{Method of collecting data}

1) Literature: The authors conducted a study of literature to find references related to the Decision Support System (DSS), Personal Home Page (PHP), My Structured Query Language (MySQL), books, text, journals and scientific works as a review of the literature to support research that does not deviate from the context.

2) Field Observation: Writers make a field trip to collect the necessary data is based on information FH Dian Suryadi, SE Paskibraka 2016 Selection Coordinator Kutai regency for participants judging criteria.

3) Interview: The authors conducted interviews to $\mathrm{Mr}$. FH Dian Suryadi, SE to get the value criteria and the father Akhmad Dwi Ari Saputra, Amd.Kep to get the value of health.

\subsection{Stage analysis}

In the next stage of data analysis required data in the form of health values, interviews, physical ability, high body, and the value of the United Nations. The value is obtained from the recapitulation during selection done. The values will then be calculated using the AHP and TOPSIS methods.

\subsection{Modeling of AHP-TOPSIS method}

The initial phase of this system is a pad by clicking the input value comparison of each criterion by using the standard value comparison of AHP, then input the results are processed using AHP to obtain eigenvalues. Eigen value is then used to find the value of concistency ratio, if in accordance with the standard value of concistency ratio continued to the calculation process by using TOPSIS method, otherwise it will repeat again to input the value of each criteria comparison. At the stage of using TOPSIS method will find the best solution of each alternative. Alternate data of selection participants entered and then stored. These alternatives have data in the form of health values, interviews, physical ability, high body and value rules for marching which is then used to find the value of each alternative weight. The best preference value would be PASKIBRAKA member recommendation of 21 sons and 21 daughters.

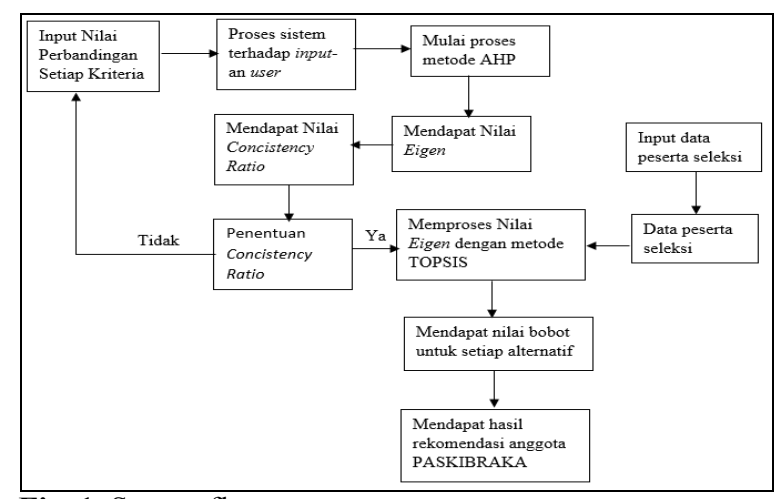

Fig. 1. System flow

\section{Results and discussion}

\subsection{System analysis}

AHP method is used as the first process base whose input value comes from admin and get the result of weight value criteria will be processed in the next calculation using TOPSIS method. The first stage in the system process is to include the comparative value of each criterion based on the standard AHP comparison value.

The second stage, the system will arrange the value of the comparison that has been inputted into a matrix of equation comparison. The third stage, after being a comparison matrix of equations, then the matrix is normalized. The fourth stage, the matrix normalization in total per line criteria provided then divided by 5 according to the number of criteria available produce eigen value / weight value.

The fifth stage, eigen values / weight value is then used to find the value consistency index, if the value $\mathrm{CR}$ of the calculation process AHP qualify CR (Consistency Ratio) received $\mathrm{CR} \leq 0.1$ then the calculation process can be continued to methods TOPSIS, if No admin is required to enter again the criterion comparison value. The next stage is using TOPSIS method to search for the best alternative. The seventh stage, the system will store the critical weight value of the AHP method and then the admin will input the weight value of each 
alternative. The value of alternative weight is then made into matrix and normalized.

The eighth stage, after normalization of the alternative assessment continued with weighted normalization using the weighted value criteria that have been obtained in the AHP calculation process. The ninth stage computes the ideal positive and ideal solution that produces the positive and negative ideal spacing of each alternative at the tenth stage. The final stage calculates the preference value for each alternative followed by sorting the preference value.

The recommendations are the best preferences of 21 alternative male and 21 female alternatives.

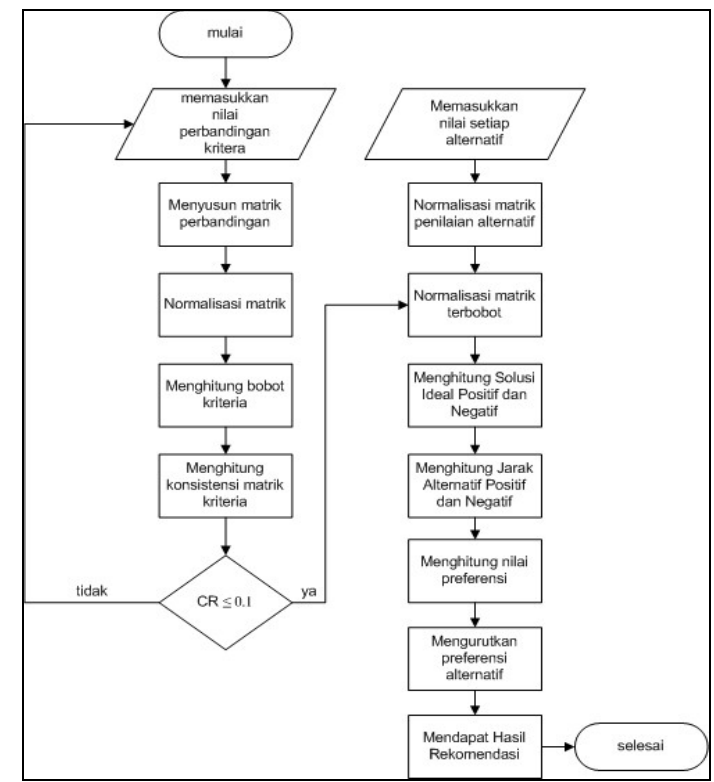

Fig. 2 calculation process flow system

\subsection{System Implementation}

Implementation system is a stage that is done after the system has been built based on the designs that have been made.

\subsection{Home Page}

Home Page contains an explanation of the method of AHP and TOPSIS on Selection Paskibraka and how to use this system. Homepage menu display can be seen in Figure 4.

\section{A Beranda 国Hasil \& Perhitungan O Tentang Admin -}

\section{Pemilihan Anggota Paskibraka}

$$
\text { A SPK AHP-TOPSIS / Artikel }
$$

Pemilihan Paskibraka Menggunakan Metode AHP (Analytic Hierarchy Process) dan TOPSIS (Technique For Order Preference by Similarity to Ideal Solution)

Aplikasi ini dibuat untuk memberikan alternatif terbaik untuk pemilihan anggota Paskibraka menggunakan kombinasi metode AHP dan TOPSIS. Hasil dari aplikas ini berupa rekomendasi alternatif terbaik sebanyak 21 Putra dan 21 Putri.

Tentang Metode AHP (Analytic Hierarchy Process)

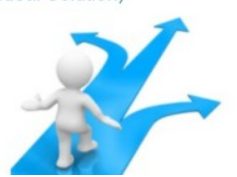

\section{4 calculations page}

On the Calculation page displays detailed calculations of AHP and TOPSIS methods starting from calculating the criteria weighted value to an alternative preference value. The Calculation page shows the entire system calculation from matrix comparison to alternative sorting based on value of preference / value of weighted criteria obtained. Calculation menu view can be seen in figure 4 .
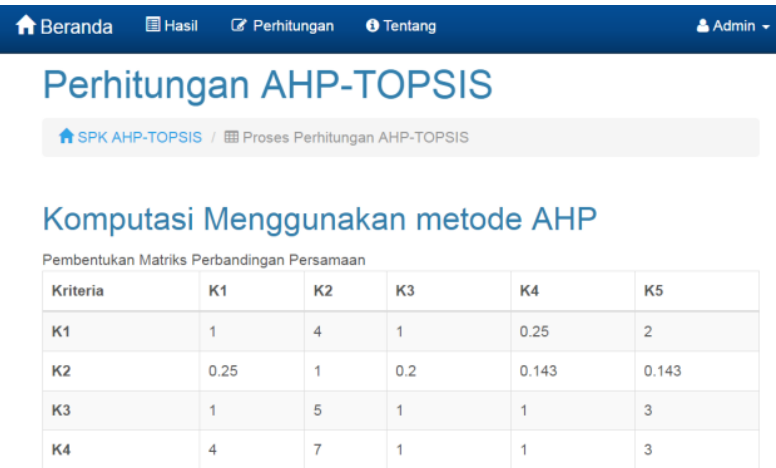

Fig. 4. Calculation Page

\subsection{Result Page}

Display Results menu displays the results of system recommendations based on the value of weight that has been entered by the admin. The recommendations in the form of 21 male and female names along with the school of origin and final score calculations. result page display can be seen in Figure 5.

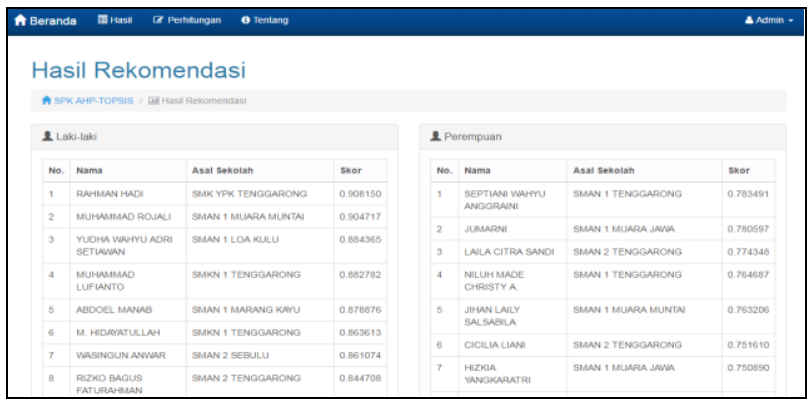

Fig. 5. Page Results

\subsection{System testing}

System testing is done to determine the extent to which the success of the calculation of decision support systems that have been built. At this stage, the system will be tested by comparing the calculation of AHP and TOPSIS system with AHP and TOPSIS calculations performed manually.

Fig. 3. Home Page 
Table 2. Sample Selection Participants Paskibraka

\begin{tabular}{|c|c|c|c|c|c|c|c|c|}
\hline \multirow[b]{2}{*}{ No } & \multirow[b]{2}{*}{ NAME } & \multirow{2}{*}{$\begin{array}{l}\text { PARTICIPANTS'S } \\
\text { NUMBER }\end{array}$} & \multirow{2}{*}{$\begin{array}{c}\text { WHICH } \\
\text { SCHOOL ARE } \\
\text { YOU FROM }\end{array}$} & \multicolumn{3}{|c|}{ SELECTION RESULT } & \multirow[b]{2}{*}{ Height } & \multirow[b]{2}{*}{ UN } \\
\hline & & & & Health & Interview & Physical test & & \\
\hline 1 & $\begin{array}{l}\text { MUHAMMAD } \\
\text { ROJALI }\end{array}$ & 002 & \begin{tabular}{c|} 
SMAN1 \\
Ma.MUNTAI
\end{tabular} & s & A & 76 & 171 & 70 \\
\hline 2 & $\begin{array}{l}\text { YUDHA } \\
\text { WAHYU ADRI } \\
\text { SETIAWAN }\end{array}$ & 278 & $\begin{array}{c}\text { SMAN 1 LOA } \\
\text { KULU }\end{array}$ & s & B & 71 & 173 & 70 \\
\hline 3 & $\begin{array}{l}\text { THE RAHMAN } \\
\text { HADI }\end{array}$ & 251 & SMK YPK TGR & s & A & 70 & 172 & 90 \\
\hline 4 & $\begin{array}{l}\text { ABDOEL } \\
\text { MANAB }\end{array}$ & 254 & $\begin{array}{c}\text { SMAN } 1 \\
\text { Ma.WOOD }\end{array}$ & s & B & 68 & 170 & 89 \\
\hline 5 & $\begin{array}{l}\text { MUHAMMAD } \\
\text { LUFIANTO }\end{array}$ & 052 & SMKN 1 TGR & $s$ & B & 70 & 168 & 80 \\
\hline
\end{tabular}

Table 3. Selection Criteria Paskibraka

\begin{tabular}{|c|c|}
\hline Criteria & Criteria code \\
\hline Health & $\mathrm{K} 1$ \\
\hline Interview & $\mathrm{K} 2$ \\
\hline Physical test & $\mathrm{K} 3$ \\
\hline Height & $\mathrm{K} 4$ \\
\hline marching & $\mathrm{K} 5$ \\
\hline
\end{tabular}

1. Calculation of AHP method

Table 4. Table Pair Wise Comparisons

\begin{tabular}{|c|c|c|c|c|c|}
\hline Crite ria & $\mathbf{k 1}$ & $\mathbf{k 2}$ & $\mathbf{k 3}$ & $\mathbf{k 4}$ & $\mathbf{k 5}$ \\
\hline $\mathrm{k} 1$ & 1 & 4 & 1 & 0.25 & 2 \\
\hline $\mathrm{k} 2$ & 0.25 & 1 & 0.2 & 0.143 & 0.143 \\
\hline $\mathrm{k} 3$ & 1 & 5 & 1 & 1 & 3 \\
\hline $\mathrm{k} 4$ & 4 & 7 & 1 & 1 & 3 \\
\hline $\mathrm{k} 5$ & 0.5 & 7 & 0.333 & 0.333 & 1 \\
\hline amount & 6.75 & 24 & 3.533 & 2.726 & 9.143 \\
\hline
\end{tabular}

Table 5 Table Normalized Matrix Pair Wise Comparisons

\begin{tabular}{|c|c|c|c|c|c|c|c|}
\hline criteria & $\mathrm{k} 1$ & $\mathrm{k} 2$ & $\mathrm{k} 3$ & $\mathrm{k} 4$ & $\mathrm{k} 5$ & $\mathrm{Jumlah}$ & $\begin{array}{c}\text { Average } \\
\text { priority weight }\end{array}$ \\
\hline $\mathrm{k} 1$ & 0.148 & 0.166 & 0.283 & 0.091 & 0.218 & 0.908 & 0.182 \\
\hline $\mathrm{k} 2$ & 0.037 & 0.041 & 0.056 & 0.052 & 0.015 & 0.203 & 0.041 \\
\hline $\mathrm{k} 3$ & 0.148 & 0.208 & 0.283 & 0.367 & 0.328 & 1.335 & 0.267 \\
\hline $\mathrm{k} 4$ & 0.592 & 0.291 & 0.283 & 0.367 & 0.328 & 1.862 & 0.372 \\
\hline $\mathrm{k} 5$ & 0.074 & 0.291 & 0.093 & 0.121 & 0.109 & 0.689 & 0.138 \\
\hline
\end{tabular}

Table 6. Vector Weight Value

\begin{tabular}{|c|}
\hline Vector of weight \\
\hline 0.981 \\
\hline 0.212 \\
\hline 1.439 \\
\hline 2.066 \\
\hline 0.727 \\
\hline
\end{tabular}

Calculating CR value

$\lambda_{\max }=\frac{((0.981 / 0.182)+(0.212 / 0.041)+(1.439 / 0.267)+(2.066 / 0.372)+(0.727 / 0.138))}{5}$

$$
=5.361
$$

$C I=\frac{5.361-5}{5-1}=0.090$

$C R($ Consistency Ratio $)=\frac{0.090}{1.12}=0.080$

By CR (Consistency Ratio) generated is less than 0.1 or $C R \leq 0.1$, the final result can be justified and can proceed to the next step and conclude that the comparison between the criteria consistently.

2. Calculation of TOPSIS method

Table. 7 Alternative Assessments

\begin{tabular}{|c|c|c|c|c|c|}
\hline \multirow{2}{*}{$\begin{array}{c}\text { Alternative/ } \\
\text { No } \\
\text { participants }\end{array}$} & \multicolumn{5}{|c|}{ Alternative Rating Matrix } \\
\cline { 2 - 6 } & K1 & K2 & K3 & K4 & K5 \\
\hline 002 & 5 & 5 & 76 & 171 & 70 \\
\hline 052 & 5 & 3 & 70 & 168 & 80 \\
\hline 251 & 5 & 5 & 70 & 172 & 90 \\
\hline 278 & 5 & 3 & 71 & 173 & 70 \\
\hline 254 & 5 & 3 & 68 & 170 & 89 \\
\hline
\end{tabular}

Table. 8 Normalized Matrices Weighted

\begin{tabular}{|l|l|l|l|l|l|}
\hline \multirow{2}{*}{$\begin{array}{l}\text { Alternative/ } \\
\text { No } \\
\text { participants }\end{array}$} & \multicolumn{5}{|c|}{ Normalized Matrix Weighted } \\
\cline { 2 - 6 } & K1 & K2 & K3 & K4 & K5 \\
\hline 002 & 0.081 & 0.023 & 0.127 & 0.166 & 0.053 \\
\hline 052 & 0.081 & 0.013 & 0.117 & 0.163 & 0.061 \\
\hline 251 & 0.081 & 0.023 & 0.117 & 0.167 & 0.069 \\
\hline 278 & 0.081 & 0.013 & 0.119 & 0.168 & 0.053 \\
\hline 254 & 0.081 & 0.013 & 0.114 & 0.165 & 0.068 \\
\hline
\end{tabular}

Table 9 Positive Ideal Matrix Solutions \& Ideal Negative

Matrix Solutions

\begin{tabular}{|c|c|c|c|c|c|}
\hline & K1 & K2 & K3 & K4 & K5 \\
\hline $\mathrm{K}^{+}$ & 0.081 & 0.023 & 0.127 & 0.168 & 0.069 \\
\hline $\mathrm{K}^{-}$ & 0.081 & 0.013 & 0.114 & 0.163 & 0.053 \\
\hline
\end{tabular}

Table 10 Positive Distance Matter and Alternative Negative

\begin{tabular}{|c|c|c|}
\hline \multicolumn{3}{|c|}{ Distance } \\
\hline Alternative & Distance + & Distance - \\
\hline 2 & 0.0155 & 0.0166 \\
\hline 52 & 0.016 & 0.008 \\
\hline 251 & 0.010 & 0.0187 \\
\hline 278 & 0.0198 & 0.007 \\
\hline 254 & 0.0166 & 0.0147 \\
\hline
\end{tabular}

$$
V_{2}=\frac{0.01663}{0.01663+0.0155}=0.517
$$




$$
\begin{aligned}
\mathrm{V}_{52} & =\frac{0.008}{0.008+0.016} \\
= & 0.337 \\
\mathrm{~V}_{251} & =\frac{0.0187}{0.0187+0.010} \\
= & 0.648 \\
\mathrm{~V}_{278} & =\frac{0.007}{0.007+0.0198} \\
= & 0.260 \\
\mathrm{~V}_{254} & =\frac{0.0147}{0.0147+0.0166} \\
= & 0.469
\end{aligned}
$$

\begin{tabular}{|c|c|c|c|}
\hline \multicolumn{2}{|c|}{ A Beranda G Hasil $\mathbb{E}$ Perhitungan } & (- Tentang & S Admin \\
\hline \multicolumn{4}{|c|}{ Hasil Rekomendasi } \\
\hline \multicolumn{4}{|c|}{ A SPK AHP-TOPSIS / 四 Hasil Rekomendasi } \\
\hline \multicolumn{4}{|c|}{2 Laki-laki } \\
\hline No. & Nama & Asal Sekolah & Skor \\
\hline 1 & RAHMAN HADI & SMK YPK TENGGARONG & 0.908150 \\
\hline 2 & MUHAMMAD ROJALI & SMAN 1 MUARA MUNTAI & 0.904717 \\
\hline 3 & $\begin{array}{l}\text { YUDHA WAHYU ADRI } \\
\text { SETIAWAN }\end{array}$ & SMAN 1 LOA KULU & 0.884365 \\
\hline 4 & MUHAMMAD LUFIANTO & SMKN 1 TENGGARONG & 0.882782 \\
\hline 5 & ABDOEL MANAB & SMAN 1 MARANG KAYU & 0.878876 \\
\hline
\end{tabular}

Table 11 Preference Value

\begin{tabular}{|c|c|c|c|}
\hline Alternative & Preference & $\begin{array}{c}\text { Alternate } \\
\text { Sequence }\end{array}$ & $\begin{array}{c}\text { Preference } \\
\text { Sequence }\end{array}$ \\
\hline 2 & 0.517 & 251 & 0.648 \\
\hline 52 & 0.337 & 2 & 0.517 \\
\hline 251 & 0.648 & 254 & 0.469 \\
\hline 278 & 0.2608 & 52 & 0.337 \\
\hline 254 & 0.469 & 278 & 0.260 \\
\hline
\end{tabular}

The order of selection of members Paskibraka recommendations were counted manually in the order recommendation Paskibraka members is calculated using the system seen in Figure 10 with the difference of each alternative 0001 .

Fig. 6. System Calculation Results

\subsection{Validation of results}

After testing the calculation of the system run in accordance with the manual calculation then input all participants as much as 73 men and 69 women. All participants of the election Paskibraka alternative stored next step is to do a comparison of the value of the 5 existing criteria namely health, interview, physical test, height, and the value of the UN. Then the results of recommendations based on the system validated against the results of selection conducted directly by the Dispora Kutai Kartanegara.

The validation result between the recommendation of the system and the direct selection by the committee is $40.47 \%$ value less than $50 \%$ so it is assumed the result of less precise but precise calculation method. The result of validation is very less because there are several factors that can not be calculated by the system such as preferably the members paskibraka school and the appearance of the selection participants.

\section{Conclusion}

Analytical Hierarchy Process (AHP) and Technique For Order Preference By Similarity To Ideal Solution (TOPSIS) successfully applied in decision support system of Paskibraka selection in Youth and Sports Department of Kutai Kartanegara Regency. The criteria chosen in this research are health, interview, physical test, high body, and PBB can be processed and then produce recommendation through stages that have been specified in method AHP and TOPSIS

\section{References}

1. S. Maharani, HR. Hatta, G. Merdiko, " Articles of Bali International Seminar On Science and Technology. (2014)

2. D. U. Daihani, Computerized Decision Making. Bogor: Ghalia Indonesia. (2001)

3. Kusrini. Concept and Application of Decision Support System. Yogyakarta: Andi Offset. 2007.

4. Regulation of the Minister of Youth and Sports of the Republic of Indonesia Number 0065 of 2015.

5. Padmowati, RdLE, Measurement Index Consistency In Decision Making Process Using AHP Method. Semnas IF. 2009.

6. Kusumadewi, Sri, et al. Fuzzy Multi Attribute Decision Making. Yogyakarta: Graha Science. 2006.

7. A. Rasyid, S. Maharani, Journal of Informatics Mulawarman Vol. 11, No. 2, September 2016."

8. W Idodo, PP, and Herlawati. Using UML (Unified Modeling Language. Bandung: Informatics, 2011.

9. JL. Whiten, and LD. Bentley, System Analysis and Design Methods Seventh Edition. New York: The McGraw-Hills Company. 2007. 